\title{
Experiential Marketing Leading to Behavioural Intention - Testing the Mediation Effects of Information Search Cost
}

\author{
Chi-Hsien Kuo, Shin'ya Nagasawa \\ Graduate School of Commerce, Waseda UniversityBusiness School, Tokyo, Japan \\ Email address: \\ theone.reine@gmail.com (Chi-Hsien Kuo),nagasawa@waseda.jp (S. Nagasawa)
}

\section{To cite this article:}

Chi-Hsien Kuo, Shin'ya Nagasawa. Experiential Marketing Leading to Behavioural Intention? Testing the Mediation Effects of Information Search Cost. Science Journal of Business and Management. Special Issue: Customer Experience Management/Marketing Branding. Vol. 3, No. 2-1, 2015, pp. 43-53. doi: 10.11648/j.sjbm.s.2015030201.15

\begin{abstract}
The luxury market has growth dramatically in the recent years. Researches for luxury market drew more attention in academic fields. This paper proposed in research model to understand the consumer consumption behavior based on the experiential marketing module proposed by Schmitt (1990). With 379 valid samples, this study found that both of sense and feel positively influenced the consumer trust and self-esteem. Indeed, information search cost fully mediated the relationship between the trust and behavioral intention, and partially mediated the relationship between the self-esteem and behavioral intention. For marketers who want to promote the market share, this study provides more comprehensive information on how to offer the efficient marketing clues to invest the limited resource on the critical variables in order to maximize the sales volume. More theoretical and managerial implications are also discussed in the last section.
\end{abstract}

Keywords: Luxury Goods, Experiential Marketing Module, Purchase Intention

\section{Introduction}

Luxury, a perception of "refined enjoyment, of elegance, of things desirable but not essential" (Goody, 2006, p. 341), is a symbol of higher social status and wealth. As Tynan et al. (2010) mentioned, luxury brand identifies high quality and expensive products that consumers are perceived as rare, exclusive, and prestigious. This market has grown in past years. According to the McKinsey \& Co. (1998) report, the market share was more than $\$ 90$ billion (USA, Europe and Scandinavia) in different business sectors, including the perfume, jewellery, watches, cars, wine, tableware, gift-ware and clothing). A report conducted by Goldman Sachs (KPMG, 2006) also indicated that luxury goods in China market were evaluated to rise from $12 \%$ in 2007 to $29 \%$ by 2015 . Indeed, Bain \& Company (2014) showed that the overall luxury market exceeded $€ 850$ billion in 2014, revealing 7\% health growth of overall market. It implies that partitioners should pay more attention to the growing of competition in this business world. However, after reviewing the extant literature, a few papers discussed about the experiential marketing in the luxury goods markets. Marketers have executed experiential marketing for such a long time in practical business environment. What is the influence and consequence for those marketing activities is quit important. Based on this research gap, this study proposes a research framework based on the experiential marketing module proposed by Schmitt (1999) to understand the relationships among those factors.

\section{Literature Review}

In this section, this paper firstly introduced the customer perceptions of luxury goods, experiential marketing module, and thus, the consequential factors related to experiential marketing modules would be introduced. Based on the related works discussion, this paper proposed a research model and developed the research hypotheses.

\subsection{Consumer Perceptions of Luxury Goods}

The word of "luxury" comes from Latin "luxuria," which means "extras of life" (Danziger, 2005). It implies that consumer seek for premium things different from their daily essential needs and demands. Luxury good is defined as apparel, accessories, handbags, shoes, watches, jewelry, and perfume (Gao et al., 2009). Consumers can obtain prestige feelings by purchasing luxury goods, that is, called conspicuous consumption (O'Cass and McEwen, 2004). Conspicuous consumption also represents consumers need to 
pay more monetary costs to get something different and specific. Ahmed et al. (2004) indicated that luxury goods represent the taste/aroma, prestige, and high quality. The design style reflects a designer thought, life style, and the passion toward the art. The sense toward these products may differentiate from consumers and viewers. Prior researches indicated that luxury goods were associated with wealth, exclusively and power, and have been identified with satisfaction of nonessential wants (Dubois and Laurent, 1994; Brun et al., 2008), similar to "relate" concept from the Schmitt's (1999) experiential marketing modules. In addition, priors studies indicated that luxury good (i.e., clothes) could be implied to innovation which means that manufacturers often spent their expenses to investigate new technique for making product to pursue the higher quality and standard (Amatulli and Guido, 2011). In spite of the conspicuous consumption was regarded as a symbol of social status or innovativeness in an advanced producing process; those concepts need to be taken into consideration through a systematic approach. In a short, this paper applied a holistic view based on the Schmitt's (1999) to examine the consumer perceptions toward to the behavioral intention.

\subsection{Experiential Marketing Module}

Experience has been considered as behavior that is reflected in pre-purchase trials (Wright, 1974). Singh et al. (2000) indicated that direct experience has more influence on recall, attitudes, and purchase intentions than ordinary advertising. With positive use experience about the product or service, consumers probably become knowledgeable about the brand and a loyal client (Keller, 2003). Since there are a few studies discuss the experience by a systematic view (Yoon, 2013, p 695), Schmitt (1999) proposed a framework for strategic experiential modules (SEMs), including sense, feel, think, act, and relate. As he mentioned, "experiential marketing view consumers as rational and emotional human beings who are concerned with achieving pleasurable experiences." (Schmitt, 1999, p. 53) Marketers need to reexamine product, services, and marketing activities from different perspectives. According to SEMs, sense refers to the appeals to the sense with the objective of creating sensory experiences, through sight, sound, touch, taste, and smell. Sense is a cognitive orientation element such as fresh and new. Secondly, feel, appeals to consumers' psychological elements such as feelings and emotions. During the consumption, how to let consumers trigger certain positive emotions is difficult and it may be different from culture to culture. Arousing consumer positive emotion is critical since it leads a higher level of satisfaction and behavioral intention (Tsaur et al., 2006). Third, think refers to intellect with the objective of creating cognitive, problem-solving experiences in which stimulate customers creatively. It is related with new technology, innovativeness that can let consumer associate with something different. Forth, act engage consumer in approaching the target life goals by showing them the ways to achieve. For example, a slogan in a sport shoes advertisement said "Just do it" showing the stimulus for consumers to evoke behavioral changes. Fifth, last but not least, relate results from relating to a reference group or culture, composing of sense, feel, think, and act marketing. It related with personal desire for self-improvement or entering an ideal social identity.

Based on the SEMs, Yoon (2013) applied the SEMs to comprehend the in-store shopping experience, including the experiences from department stores and discount stores. The empirical results showed that shopping motives had significant effects on shopping experiences. Both of department store and discount store moderated between experience-based motive and affective experiences. In this study, we but only view experiential marketing as a promote strategy to encourage consumer to purchase product or service toward the pre-purchasing behavior, but we consider that this marketing strategy may ferment its effects on during or post-purchasing situation. For example, Tsaur et al. (2006) examined the experiential marketing effect when visitors surfing in the zoo. During the consumption (in the zoo), visitors simultaneously engage in an experiential environment and create their own experience. In addition, those own experience may still pervade and spread after their consumption behavior.

\subsection{Trust}

Urban et al. (2000) indicated that trust play an essential role between customers and service providers to build up and sustain a relationship. Moorman et al. (1993) defined trust as "a willingness to rely on an exchange partner in whom on has confidence." It means that consumer may have confidence in provider's service and product, and thus, trigger their intention to purchase behaviors. Similarly, Morgan and Hunt (1994, p.23) referred trust as the conception of "confidence in the exchange partner's reliability and integrity." Both of definitions emphasized the concept of consumers' confidence in service providers. Therefore, this paper defined consumer trust as the expectations held by the consumer that the product provider is dependable and can be relied on to deliver on its promises.

Prior studies paid attention to the consequences of customer trust such as loyalty (Sirdeshmukh et al., 2002; Garbarino and Johnson 1999), representing that a stable relationships between a client and a merchandiser. As Reichheld and Schefter (2000, p. 107) mentioned, "(To) Gain the loyalty of customers, you must first gain their trust." How to construct and support consumer trust is an essential issue. Moorman et al. (1993) indentified factors influence consumer trust such as perceived expertise, integrity, and congeniality. For example, if a luxury company applies the newest technique to produce their product, it may enhance the consumer perception of expertise.

\subsection{Information Search Cost}

In order to decrease the uncertainty toward a product, consumer may spend any forms of costs to gather the related information (Shugan, 1980). Information search cost represents the expenditure of time, money, and psychological 
cost when consumer looking for the product information. The level of information search cost depends on the level of perceived risk from consumer. When consumers have the greater level of risk consumer perceived, the greater time they would spend to gather information. According to the multiattribute utility theory (Leuthesser, 1988), consumer utility relies on a brand's perceived physical, functional, symbolic attributes and consumer tastes. Marketers actually can provide those clues by promoting the experiential marketing activities. In this way, consumers will psychologically compare their personal needs with those attributes to make the purchasing decision, reducing the cost for searching information.

\subsection{Self-Esteem}

Brown (1993) defined self-esteem as the extent of global feeling of self-liking, self-worth, and self-acceptance. Individual with high level of self-esteem will embrace more pleasure to view themselves (Truong and McColl, 2011) and have more confidence to accept any kinds of challenges (Di Paula and Campbell, 2002). Extant researchers regarded self-esteem as a part of human ego and this psychological element will strengthen people self-evaluation to struggle with failures (Pyszczynski et al., 2004; Renaud and McConnell, 2007). Prior studies were shown that self-esteem was related with human behavioral intention. Based on their longitudinal survey conducted by Di Paula and Campbell (2002), they examined the relationships between the levels of self-esteem and the concept of knowing when to quit. Based on the empirical evidence, they found that self-esteem was positive related with achieving more goals, more satisfaction with progress toward goals, and more behavioral pursuit of goals. Judge and Bono (2001) also indicated that self-esteem was positively related with job performance. Based on the above discussion, this study describes the hypotheses as followings.

\subsection{Hypothesis Development}

\subsubsection{The Research Model}

According to Schmitt modules (1999), this study proposed a research model as shown in figure 1.

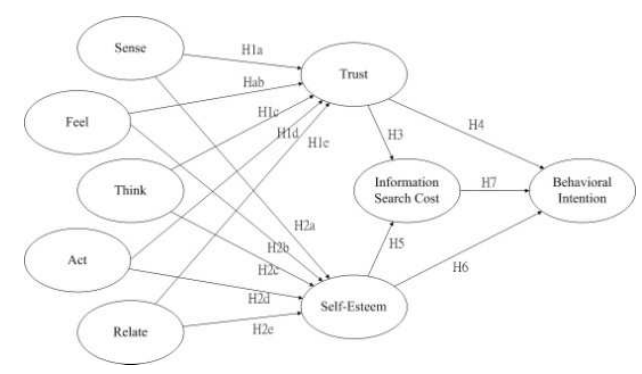

Figure 1. Research framework.

This model completes relationship network of luxury goods purchasing behavior, following by the trust and self-esteem and consumer perceptions of luxury goods. There are 9 constructs and 15 linkages between the constructs. Based on the linkages (relationships) in the research model, this paper proposes 8 postulated hypotheses (including one hypothesis about mediation effect of information search cost). The justifications of these hypotheses are discussed as follows.

\subsubsection{Hypotheses Development}

Schmitt (1999) proposed the experiential marketing and identified five important factors, namely, sense, feel, think, and relate. This paper regards those concepts as consumer perceptions toward the luxury product since they may experience the experiential marketing from service providers or they had purchased the luxury goods and have own experience of usage. Those perceptions have influence on consumer trust. Giving an example of carrying a luxury handbag, relatives or friends may easier recognize the handbag brand due to its conspicuous appearance ("sense" trigger). It leads one's trust the fact that the consumption satisfies one's needs for uniqueness (Bian and Forsythe, 2012). In addition, luxury goods give consumer the innovative (ostentatious) perceptions (Amatulli and Guido, 2011), it related with the use of new technology and advanced engineering to manufacture luxury product, and thus, enhances one's confidence in quality toward the prestige brand. During the experiential marketing activities, luxury brand can convey information passing the consumers (Erdem and Swait, 1998), increasing the consumer trust. Based on this argument, this paper postulated that:

Hla: Sense has a positive effect on Consumer trust.

$H 1 b$ : Feel has a positive effect on Consumer trust.

H1c: Think has a positive effect on Consumer trust.

H1d: Act has a positive effect on Consumer trust.

H1e: Relate has a positive effect on Consumer trust.

In addition, Wiedmann et al. (2009) described that the consumption of prestigious brands provide values such as, individual value and social value. For example, one sub-value within the individual value was called hedonic value which describes the concept of luxury consumption was associated with sensory pleasure and excitement (Roux \& Floch, 1996; Vigneron \& Johnson, 2004), similar with feel marketing. With the pleasure feeling, consumer can obtain self-worth which belongs to the extent of self-esteem. Further, the concept of relate marketing causes from a comparison with reference group (Schmitt, 1999). Wang et al. (2010) indicated that social comparison reveals one's motivation for comparing self with others. By performing the conspicuous consumption, consumers could obtain a perception of self-worth since they regards this merchandise as a symbolic meaning of entering a higher social status (Holt, 1995). Consumers' self-acceptance was arisen from this process, representing the extant of self-esteem (Brown, 1993). Therefore, this paper postulated that:

H2a: Sense has a positive effect on Consumer self-esteem.

$H 2 b$ : Feel has a positive effect on Consumer self-esteem.

H2c: Think has a positive effect on Consumer self-esteem.

H2d: Act has a positive effect on Consumer self-esteem.

H2e: Relate has a positive effect on Consumer self-esteem.

The proposed relationship between consumer trust and 
behavioral intention is supposed by reciprocity arguments. When experiential marketing act builds up the consumer trust, the clarity about product attributes and functions will increase. It leads consumers to reducing the information search cost (Erdem and Swait, 1998; Erdem et al., 2006). Indeed, it also enables consumers to make more confidence in predicting the future performance of luxury brand (Mayer et al., 1995). Facing a trustworthy luxury brand, consumer will demonstrate their loyalty by behavioral evidences (Gassenheimer et al., 1998). For example, they are able to share their personal opinions praise with their close friends. Here, this paper postulated that:

H3: Consumer trust has a positive influence on information search cost.

H4: Consumer trust has a positive influence on behavioral intention.

Arndt et al. (2004) described consumer behavior as they acquiring product help themselves to improve self-esteem by flattering one's ego. This concept appropriately depicts the luxury goods consumption since there are social values obtained by performing this consumption behavior. Prior studies indicated that intrinsic goals are theorized to be more valuable than extrinsic goals (Kasser, 2002), it meant that consumer would firstly pursue the higher level of intrinsic value (self-esteem), thus reducing the extrinsic value (information search cost). More specifically, luxury consumption support and improve self-worth, representing an essential constituent of self-esteem (Mick and Demoss, 1990). Sheldon et al. (2001) proposed that self-esteem was regarded as a fundamental need which integrate with goal pursuit and play an essential role in motivation theories and self-concept theories in marketing (Ferraro et al., 2005; Hogg et al., 2000). For instance, Amatulli and Guido (2011) conducted a hierarchical value map by mean-end-chain method and demonstrated that self-confidence and self-fulfillment are the main hidden final values when buying and consuming luxury goods. Those values construct and form one's self-esteem. According to prior studies, self-esteem positively influences consumer intention (Truong and McColl, 2011). Base on the argument, this paper postulated that:

H5: Consumer self-esteem has a positive influence on information search cost.

H6: Consumer self-esteem has a positive influence on behavioral intention.

Prior studies have shown that information search cost has a positive influence on consumer behavioral intention since there were enough clarity about the product or service (Erdem et al., 2006; Erdem and Swait, 1998). From the utilitarian motivation perspective, when consumers perceived the efficacy of searching production information, the greater probability they have to perform the consumption behavior or loyalty. Based on this point of view, this paper postulated that:

H7: Information search cost has a positive effect on behavioral intention.

Extant literature provided the evidences that trust and self-esteem have a positive effect on behavioral intention respectively (Mayer et al., 1995; Gassenheimer et al., 1998;
Baumeister et al., 2003). With experiential marketing context, this paper postulated that information search cost would play the mediator role in the relationship of trust and behavioral intention, and the relationship of self-esteem and behavioral intention. Since experiential marketing activities provide an environment and unique experience for customer to sense, feel, think, act, and relate. Those experiences would enhance their emotional and cognitive feedbacks which lead to generate a higher level of clarity of the product and self-acceptance. Indeed, it should enhance consumers' conscious of the deduction of information search cost, thus, leading to perform the behavioral intention. Purchasing or using luxury goods were regarded as being closely bounded to psychological issues, "There is a progression from the material or concrete nature of the attributes to the intangibility or experiential aspects of their effects (Amatulli and Guido, 2011, p. 130)." Therefore, this paper postulated that:

H8a: Information search cost will mediate the effect of trust on the behavioral intention.

H8b: Information search cost will mediate the effect of self-esteem on the behavioral intention.

\section{Methodology}

\subsection{Identifying the Consumer Conception of Schmitt Experiential Modules}

For the purpose of this research, this paper firstly indentified the consumer perceptions of experiential marketing by reviewing the literature of luxury goods. Thus, researchers invited the experts to refine the items by checking the wording and meaning of each items, and eliminating the duplicate items. Fifteen items were reserved. In order to integrate the retained items into Schmitt's modules (1999), this paper classified the items into five classifications, namely, sense, feel, think, act, and relate. And a pilot study was conducted to ensure the structural interrelationships among the classifications. Through the independent sample drawn from the e-commerce luxury website $(n=98)$, respondents were asked to indicate their agreement and disagreement as to whether they felt that item description could be used to depict the luxury handbags, ranging from strongly disagree (1) to strongly agree (7). Therefore, Kaiser-Meyer-Olkin (KMO), Bartlett test of sphericity (Snedecor and Cochran, 1989) and exploratory factor analysis (EFA) were performed after data collection. The results of KMO and Bartlett test were .867 and $X^{2}$ : 3495.399 ( $d f: 91$ and $\mathrm{p}<.000$ ) respectively, showing the correlations are significant with respect to non-zero correlations. In the other word, this data set was suitable for factor analysis suggested by Kalaycı (2005).

For the EFA, principle component analysis with VARIMAX orthogonal rotation (Fabrigar et al., 1999) was used to reduce the data and identify latent themes. During the iteration process, researchers discarded the cross loading items and eliminated the items with loadings less than 0.6 (Hair et al., 1998) and one item was omitted. The number of remaining items was fourteen. The results of EFA were shown 
in the Table 1.

Table 1. The results of exploratory factor analysis.

\begin{tabular}{|c|c|c|c|c|c|}
\hline Items & Sense & Feel & Think & Act & Relate \\
\hline When it comes to the characteristics of luxury goods, I think it is conspicuous. & 0.699 & 0.366 & 0.101 & 0.140 & 0.254 \\
\hline When it comes to the characteristics of luxury goods, I think it is instantly recognized by friends & 0.856 & -0.041 & 0.111 & 0.254 & -0.007 \\
\hline When it comes to the characteristics of luxury goods, I think it is for wealthy. (Deleted) & - & - & - & - & - \\
\hline When it comes to the characteristics of luxury goods, I think it is innovativeness. & -0.035 & 0.831 & 0.220 & 0.100 & 0.237 \\
\hline When it comes to the characteristics of luxury goods, I think it is use of new technology. & 0.162 & 0.789 & 0.085 & 0.270 & 0.095 \\
\hline When it comes to the characteristics of luxury goods, I think it is exclusive. & 0.130 & 0.709 & 0.259 & 0.158 & 0.275 \\
\hline Purchasing this product can let me feel at ease. & 0.075 & 0.166 & 0.735 & 0.122 & 0.155 \\
\hline Purchasing this product can let me feel self-fulfillment. & 0.095 & 0.192 & 0.816 & 0.258 & 0.295 \\
\hline Purchasing this product can let me feel gratification. & 0.106 & 0.176 & 0.827 & 0.218 & 0.285 \\
\hline This luxury brand is a symbol of social status. & 0.199 & 0.245 & 0.228 & 0.777 & 0.214 \\
\hline A person who wears luxury fashion brands appears financially successful. & 0.161 & 0.146 & 0.185 & 0.883 & 0.195 \\
\hline A person who wears luxury fashion brands appears to be a member of a high social class. & 0.161 & 0.181 & 0.194 & 0.879 & 0.185 \\
\hline I would seriously consider purchasing this brand. & 0.160 & 0.161 & 0.234 & 0.171 & 0.794 \\
\hline If I were going to purchase a luxury product, I would consider buying this brand. & 0.069 & 0.236 & 0.227 & 0.235 & 0.855 \\
\hline
\end{tabular}

Extraction method: principal component analysis; Rotation: Varimax method. Factor loadings $>0.6$ are highlighted.

\subsection{Measurement Development, Data Collection, and Procedure}

All questionnaire items were adapted from the extant studies. Table 1 and 3 exhibits all measurement items and their corresponding constructs, along with the sources of each construct. For the validity of measurement, researchers amended the wording of each item into the research context. Items was measured by a 7-point Likert-type scale, ranging from 1 (strongly disagree) to 7 (strongly agree). This study built an online survey soliciting respondents with conspicuous consumption experience. Comparing with a conventional mail-based survey, the web-based data collection has three advantages, including (1) the respondents will not be restricted to the geographical limitations; (2) economize the research expenses; and (3) shorten the data collection frame (Tan \& Teo, 2000). Furthermore, to avoid the invalid responses, the survey system checked all items are filled out by each respondent before data storing into the database. To stimulate the responding rate, researchers posted the research announcement in several websites related with luxury goods such as e-commerce websites, online forums, and bulletin board systems. To ensure the sample representative, respondents were asked to answer the questions regarding their conspicuous consumption experience.

\section{Research Findings}

\subsection{Demographics of Respondents}

After the data collection, a total of 379 valid respondents were included in this study, satisfying the suggested level by Marcoulides and Saunders (2006).

The proportion of male and female were $27.2 \%(\mathrm{n}=103)$ and $72.8 \%(n=276)$. Over $67.1 \%(n=254)$ of respondents were between the ages of 21 and 40. Regarding the education level, the majority of respondents were bachelor $(68.1 \%, n=258)$. For the marital status, approximately $55.9 \%(n=212)$ of the respondents were single and $39.3 \%(n=149)$ were married.

When it comes to the purchasing behavior of luxury goods, approximately $58.8 \% \quad(n=223)$ of respondents bought 1-3 items in the past six months. For money spending on one luxury good, $52.8 \%$ of respondents spent approximately $\$ 301$ to $\$ 900$ on one luxury item. More details are shown in Table 2.

Table 2. Demographics of respondents.

\begin{tabular}{|c|c|c|c|}
\hline Measure & Items & $\begin{array}{l}\text { Number } \\
\text { (n) }\end{array}$ & $\begin{array}{l}\text { Percentage } \\
(\%)^{*}\end{array}$ \\
\hline \multirow{2}{*}{ Gender } & Male & 103 & 27.2 \\
\hline & Female & 276 & 72.8 \\
\hline \multirow{5}{*}{ Age } & Under 20 & 6 & 1.6 \\
\hline & $21-30$ & 123 & 32.5 \\
\hline & $31-40$ & 131 & 34.6 \\
\hline & $41-50$ & 91 & 24.0 \\
\hline & 51 or order & 28 & 7.3 \\
\hline \multirow{4}{*}{ Education } & $\begin{array}{l}\text { Junior High } \\
\text { School (or less) }\end{array}$ & 0 & 0.0 \\
\hline & High School & 33 & 8.7 \\
\hline & $\begin{array}{l}\text { Undergraduate / } \\
\text { College / Bachelor }\end{array}$ & 258 & 68.1 \\
\hline & Graduate or above & 88 & 23.2 \\
\hline \multirow{4}{*}{ Marital Status } & Married & 149 & 39.3 \\
\hline & Single & 212 & 55.9 \\
\hline & Divorced & 16 & 4.3 \\
\hline & Separated & 2 & 0.5 \\
\hline \multirow{5}{*}{$\begin{array}{l}\text { How many items } \\
\text { did you purchase in } \\
\text { recently six } \\
\text { months? }\end{array}$} & No item & 114 & 30.1 \\
\hline & 1-3 Items & 223 & 58.8 \\
\hline & 4-6 Items & 27 & 7.1 \\
\hline & 7-10 Items & 6 & 1.6 \\
\hline & $\begin{array}{l}\text { More than } 10 \\
\text { Items }\end{array}$ & 9 & 2.4 \\
\hline \multirow{7}{*}{$\begin{array}{l}\text { How much do you } \\
\text { spend on one luxury } \\
\text { item averagely? (in } \\
\text { U.S. dollars) }\end{array}$} & Under $\$ 300$ & 62 & 16.4 \\
\hline & $\$ 301 \sim \$ 900$ & 200 & 52.8 \\
\hline & $\$ 901 \sim \$ 1,800$ & 74 & 19.4 \\
\hline & $\$ 1,801 \sim \$ 27,000$ & 21 & 5.5 \\
\hline & $\$ 27,001 \sim \$ 36,000$ & 12 & 3.2 \\
\hline & $\$ 36,001 \sim \$ 45,000$ & 4 & 1.1 \\
\hline & $\$ 45,001$ and up & 6 & 1.6 \\
\hline
\end{tabular}

* The percentage is referred to the valid percentage. 


\subsection{Measurement Reliability and Validity}

Confirmatory factor analysis (CFA) was applied to assess the reliability and validity of measurement model. Basically, the factor loading of each measurement item should exceed 0.7 suggested by Hulland (1999). As shown in Table 3, the factor loading ranged from 0.677 to 0.942 , satisfying the required level. Traditionally, Cronbach's alpha is used to measure internal consistency reliability in social science research. Prior literature indicated that the use of composite reliability as a replacement (Bagozzi and Yi, 1988; Hair et al., 2012). Based on Bagozzi and Yi (1988), the value of composite reliability (CR) for a construct should surpass 0.7 , representing the acceptable level of the overall reliability in a heterogeneous data collection. As the analysis results shown in Table 3, all of construct values in research model ranged from 0.813 to 0.950 , exceeding the suggested level. Further, the values of average variance extracted (AVE) were calculated to examine the convergent validity.

Table 3. Assessment of reliability and convergent validity of measurement items.

\begin{tabular}{|c|c|c|c|c|}
\hline Construct & Items (Source) & $\begin{array}{l}\text { Factor } \\
\text { Loading }\end{array}$ & CR & AVE \\
\hline \multirow{3}{*}{ Sense } & When it comes to the characteristics of luxury goods, I think it is conspicuous. & 0.876 & 0.813 & 0.685 \\
\hline & When it comes to the characteristics of luxury goods, I think it is instantly recognized by friends & 0.776 & & \\
\hline & Purchasing this product can let me feel at ease. & 0.747 & 0.904 & 0.759 \\
\hline \multirow[t]{3}{*}{ Feel } & Purchasing this product can let me feel self-fulfillment. & 0.926 & & \\
\hline & Purchasing this product can let me feel gratification. & 0.929 & & \\
\hline & When it comes to the characteristics of luxury goods, I think it is innovativeness. & 0.855 & 0.813 & 0.702 \\
\hline \multirow[t]{3}{*}{ Think } & When it comes to the characteristics of luxury goods, I think it is exclusive. & 0.839 & & \\
\hline & When it comes to the characteristics of luxury goods, I think it is use of new technology. & 0.819 & & \\
\hline & I would seriously consider purchasing this brand. & 0.860 & 0.900 & 0.750 \\
\hline \multirow[t]{3}{*}{ Act } & If I were going to purchase a luxury product, I would consider buying this brand. & 0.919 & & \\
\hline & If I were shopping for a luxury brand, the likelihood I would purchase this luxury brand is high. & 0.815 & & \\
\hline & This luxury brand is a symbol of social status. & 0.677 & 0.880 & 0.714 \\
\hline \multirow[t]{4}{*}{ Relate } & A person who wears luxury fashion brands appears financially successful. & 0.919 & & \\
\hline & A person who wears luxury fashion brands appears to be a member of a high social class. & 0.916 & & \\
\hline & This brand delivers what it promises. (Erdem et al, 2006) & 0.889 & 0.950 & 0.827 \\
\hline & This brand's product claims are believable. (Erdem et al, 2006) & 0.908 & & \\
\hline \multirow[t]{3}{*}{ Trust } & $\begin{array}{l}\text { Over time, my experiences with this brand have led me to expect it to keep its promises, no more } \\
\text { and no less. (Erdem et al, 2006) }\end{array}$ & 0.940 & & \\
\hline & This brand has the ability to deliver what it promises. (Erdem et al, 2006) & 0.899 & & \\
\hline & Purchasing this product can let me feel to be proud of myself. (Truong and McColl, 2011) & 0.942 & 0.939 & 0.885 \\
\hline \multirow[t]{2}{*}{ Self-Esteem } & $\begin{array}{l}\text { Purchasing this product can let me feel to have a strong sense of respect for myself. (Truong and } \\
\text { McColl, 2011) }\end{array}$ & 0.939 & & \\
\hline & $\begin{array}{l}\text { Knowing what I'm going to get from this brand saves me time shopping around. (Erdem and Swait, } \\
\text { 1998) }\end{array}$ & 0.728 & 0.879 & 0.709 \\
\hline \multirow[t]{2}{*}{$\begin{array}{l}\text { Information } \\
\text { Search Cost }\end{array}$} & $\begin{array}{l}\text { In terms of this brand, I do not need to spend lots of time searching the information. (Erdem and } \\
\text { Swait, 1998) }\end{array}$ & 0.886 & & \\
\hline & $\begin{array}{l}\text { This brand gives me what I want, which saves me time and effort trying to do better. (Erdem and } \\
\text { Swait, 1998) }\end{array}$ & 0.902 & & \\
\hline \multirow{3}{*}{$\begin{array}{l}\text { Behavioral } \\
\text { intention }\end{array}$} & When someone has the similar demands, I will recommend him/her this brand. (Erdem et al, 2006) & 0.873 & 0.916 & 0.785 \\
\hline & I will recommend to others about the brand. (Erdem et al, 2006) & 0.901 & & \\
\hline & I will actively share the shopping experience with this brand. (Erdem et al, 2006) & 0.885 & & \\
\hline
\end{tabular}

The Table 3 was shown that all of AVE values in this study ranged from 0.685 to 0.885 , surpassing the standard level of 0.5 suggested by Fornell and Larcker (1981). The discriminant validity of the measurements was assessed by Fornell and Larcker (1981) approach which suggested that the values of AVE by the underlying construct is larger than the shared variance with other latent constructs. As shown in the Table 4, the square root of an AVE serves as a diagonal entry where a correlation coefficient is beneath it.

\subsection{Structural Model}

After ascertaining the reliability and validity of measurement model, this study employed a Partial Least Squares Structural Equation Modeling (PLS-SEM) (Ringle et al., 2005) to examine the proposed model. Comparing with the linear structural relation model (LISREL), PLS is less limitation of variable patterns and sample size but requires a good ability to predict and explain (Bacon, 1999; Hwang et al., 2010; Wong, 2010).

As the PLS outcomes shown in Table 5 , the results revealed the path coefficients and R-squared values while the path coefficients represents the affected level of respective constructs and the R-squared values stands for the variance of dependent variable explained by the independent constructs.

The proposed model (the model 2 in Table 5) explained the substantial amount of variance for trust $\left(\mathrm{R}^{2}=42.0 \%\right)$, self-esteem $\left(R^{2}=63.7 \%\right)$, information search cost $\left(R^{2}=22.7 \%\right)$, and Behavioral intention $\left(\mathrm{R}^{2}=41.3 \%\right)$. H1a to H1e posited that factors of experiential marketing would positively influence trust. Results in Table 5 provided the evidences to partially support these hypotheses where sense (H1a, $\beta=0.162$, $\mathrm{p}<0.010$ ), feel $(\mathrm{H} 1 \mathrm{~b}, \beta=0.322, \mathrm{p}<0.001)$, and think ( $\mathrm{H} 1 \mathrm{c}$, $\beta=0.244, p<0.001$ ) significant affected the trust respectively. 
Table 4. Assessment of discriminant validity.

\begin{tabular}{|c|c|c|c|c|c|c|c|c|c|}
\hline Construct & Sense & Feel & Think & Act & Relate & Trust & SE & ISC & BI \\
\hline Sense & 0.828 & & & & & & & & \\
\hline Feel & 0.325 & 0.871 & & & & & & & \\
\hline Think & 0.354 & 0.501 & 0.838 & & & & & & \\
\hline Act & 0.327 & 0.577 & 0.512 & 0.866 & & & & & \\
\hline Relate & 0.416 & 0.560 & 0.436 & 0.487 & 0.845 & & & & \\
\hline Trust & 0.393 & 0.560 & 0.517 & 0.457 & 0.425 & 0.909 & & & \\
\hline SE & 0.426 & 0.724 & 0.501 & 0.493 & 0.659 & 0.463 & 0.941 & & \\
\hline ISC & 0.303 & 0.368 & 0.338 & 0.434 & 0.333 & 0.451 & 0.344 & 0.842 & \\
\hline BI & 0.301 & 0.478 & 0.382 & 0.514 & 0.452 & 0.421 & 0.491 & 0.551 & 0.886 \\
\hline
\end{tabular}

*The diagonal elements represent the square roots of average variance extracted (AVE) by the constructs.

$\mathrm{SE}=$ Self-Esteem; ISC = Information Search Cost;

$\mathrm{BI}=$ Behavioral intention

Table 5. Structural equation modeling results.

\begin{tabular}{|c|c|c|c|c|}
\hline Attribute & Model 1 & Model 2 & Model 3 & Model 4 \\
\hline Sense $->$ Trust & & $0.162 * *$ & & \\
\hline Feel -> Trust & & $0.322 * * *$ & & \\
\hline Think -> Trust & & $0.244 * * *$ & & \\
\hline Act $->$ Trust & & 0.077 & & \\
\hline Relate -> Trust & & 0.033 & & \\
\hline Sense -> Self-Esteem & & $0.113 *$ & & \\
\hline Feel -> Self-Esteem & & $0.475 * * *$ & & \\
\hline Think -> Self-Esteem & & 0.097 & & \\
\hline Act $->$ Self-Esteem & & -0.021 & & \\
\hline Relate $->$ Self-Esteem & & $0.314 * * *$ & & \\
\hline Trust -> Behavioral Intention & $0.241 * * *$ & 0.097 & - & $0.098^{*}$ \\
\hline Self-Esteem -> Behavior Intention & $0.380 * * *$ & $0.307 * * *$ & - & $0.307 * * *$ \\
\hline Trust $->$ Information Search Cost & - & $0.372 * * *$ & $0.372 * * *$ & - \\
\hline Self-Esteem -> Information Search Cost & - & $0.172 * *$ & $0.171^{* *}$ & - \\
\hline Information Search Cost -> Behavioral Intention & - & $0.401 * * *$ & $0.559 * * *$ & $0.401 * * *$ \\
\hline $\mathrm{R}^{2}$ (Trust) & 0.42 & 0.420 & 0.419 & 0.420 \\
\hline $\mathrm{R}^{2}$ (Self-Esteem) & 0.637 & 0.637 & 0.638 & 0.637 \\
\hline $\mathrm{R}^{2}$ (Information Search Cost) & & 0.227 & 0.227 & \\
\hline $\mathrm{R}^{2}$ (Behavioral Intention) & 0.288 & 0.413 & 0.213 & 0.413 \\
\hline
\end{tabular}

${ }^{*} \mathrm{p}<0.05 ;{ }^{*} \mathrm{p}<0.01 ; * * * \mathrm{p}<0.001 ;-$ this relationship is not included in the model.

However, act $(\beta=0.077, \mathrm{p}=0.196)$ and relate $(\beta=0.033$, $\mathrm{p}=0.574)$ did not significantly influenced the trust. Regarding to $\mathrm{H} 2 \mathrm{a}$ to $\mathrm{H} 2 \mathrm{e}$, this study proposed that factors of experiential marketing would positively affect the self-esteem. Three of five factors significantly affected the self-esteem, that is, sense (H2a, $\beta=0.113, p<0.05)$, feel $(\mathrm{H} 2 \mathrm{~b}, \beta=0.475, \mathrm{p}<0.001)$, and relate $(\mathrm{H} 2 \mathrm{e}, \beta=0.314, \mathrm{p}<0.001)$. The remaining two factors (think and act), did not significantly influenced the self-esteem. In addition, $\mathrm{H} 3$ and $\mathrm{H} 4$ posited that trust would positively influence the information search cost and behavioral intention separately. The results were shown that trust significantly influenced the information search cost $(\beta=0.372, p<0.001)$, but not significantly influenced the behavioral intention $(\beta=0.097, p=0.059)$. Further, the results were also shown that self-esteem positively affected information search cost $(\beta=0.172, p<0.01)$ and behavioral intention $(\beta=0.307, p<001)$ separately, supporting H5 and H6. Moreover, information search cost also significantly influenced the behavioral intention $(\beta=0.401, \mathrm{p}<001)$.

$\mathrm{H} 8 \mathrm{a}$ and $\mathrm{H} 8 \mathrm{~b}$ posited that information search cost would fully mediate the relationships of trust and self-esteem on behavioral intention respectively. In order to test these two hypotheses, this study followed the process proposed by Baron and Kenny (1986). Here, this study assessed four models. Firstly, the model indicated only direct effects on behavioral intention without any mediator (model 1). Secondly, this study tested the proposed model as the partial mediation of information search cost (model 2). Thus, the third one was test the full mediation effects of information search cost (model 3). The forth model was examined pure direct effects on behavioral intention, including the mediator (information search cost) (model 4). According to the results shown in Table 5, trust and self-esteem significantly influenced behavioral intention separately in model 1 . Indeed, in the model 2, four of five hypotheses proposed in this study were significantly supported except the effect of trust on behavioral intention $(\beta=0.097, p=0.059)$. Comparing with direct effects of trust and self-esteem on behavioral intention in model 1 and model 2, it revealed that the path coefficients of trust on behavioral intention dropped from $0.241(\mathrm{p}<0.001)$ to $0.097(p>0.05)$ when mediator added into the model, indicating that information search cost fully mediated the effect of trust on behavioral intention. Furthermore, the path coefficient of self-esteem also decreased from $0.380(p<0.001)$ 
in model 1 to $0.307(\mathrm{p}<0.001)$ in the model 2 , showing the mediator effect (partial mediation) of information search cost. The results met the conditions suggested by Baron and Kenny, supporting $\mathrm{H} 8 \mathrm{a}$ and partially supporting $\mathrm{H} 8 \mathrm{~b}$. the results also shown in figure 2.

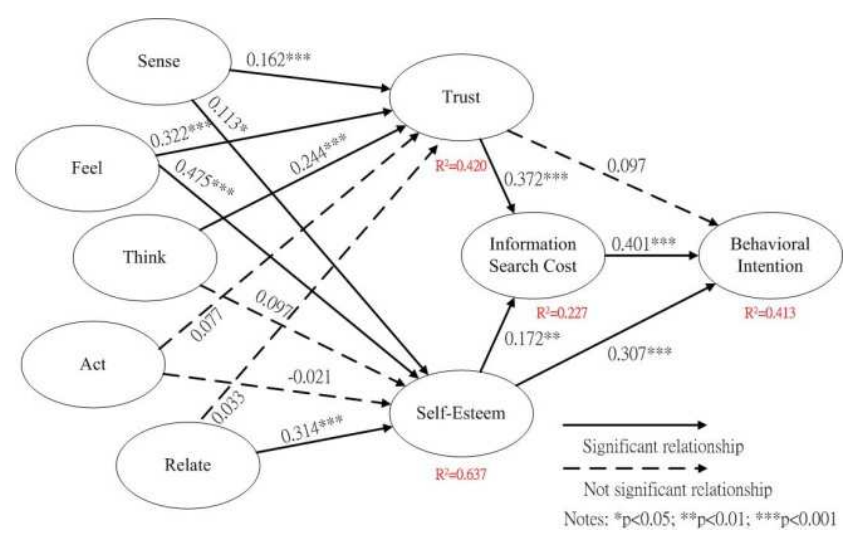

Figure 2. PLS results.

\subsection{Comparison with Alternative Models}

Since model 2 depicted the possible ways where illustrated the relationships between the constructs in the proposed model. Alternative models could give the plausible predictions and explanations about the influences of trust, self-esteem, and information search cost on behavioral intention. In model 1 and 4, this paper found that trust, self-esteem, and information search cost have direct influences on behavioral intention separately. Furthermore, model 2 and 3 described the fully and partially mediation effect of information search cost on the relationships of trust, self-esteem, and behavioral intention. To explore those possibilities, this paper compared these four models with the following two criteria: (1) the $\mathrm{R}^{2}$ of outcome variable; (2) the explanation of mediation. Regarding to the $\mathrm{R}^{2}$ of outcomes variable, the results from model 2 and 4 $\left(\mathrm{R}^{2=} 41.3 \%\right)$ were greater than the model $1\left(\mathrm{R}^{2=} 28.8 \%\right)$ and model $3\left(\mathrm{R}^{2=} 21.3 \%\right)$. Since research question of this paper is to understand the prediction of behavioral intention of conspicuous consumption, the explanation power of predictive variables is the essential criteria to take into consideration. Next, four of five hypothesized paths obtained the empirical evidences in model 2 could better illustrate the relationships among the constructs. And it helps to describe the mediation effects of information search cost on trust, self-esteem, and behavioral intention, explaining the essential role of mediator. Based on the above discussion, this paper concluded that model 2 would be a relatively applicable representation to fit this research context.

\section{Conclusion}

This study developed a research model based on the strategic experiential modules proposed by Schmitt (1999). To comprehend consumer behavioral intention toward the conspicuous consumption, this paper collected the empirical evidence to test the postulated hypotheses in the research model. Based on the 379 valid samples, most of hypotheses were statistically supported. Both of sense and feel significantly influenced the consumer trust and self-esteem. In luxury market, marketers should emphasize the style, color, and the story of product, showing the design philosophy to tough its consumers. Indeed, adding the free and relax atmosphere during the promotion activities and specialty store also can enhance the feel marketing which can increase consumers' trust and self-esteem. According to the analysis results, think marketing positively influenced on the consumer' trust but not on self-esteem. It may because the descriptions of innovations and the use of new technology could be transformed into a kind of information about provider's expertise. It helps to raise the consumer trust, similar to research findings of Moorman et al. (1993) work. However, this information would be not related with individual's self-concept about self-esteem. In contrast, the relate marketing is related to individual's self-concept. The results revealed that it had a positive influence on self-esteem, not on trust. Since the concept of relate is a comparison with reference groups (Schmitt, 1999), conspicuous consumption enhances one's self-acceptance by purchasing a high-class product. To improve one's self-esteem by conspicuous consumption, feel and relate marketing have the most influences based on the analysis results. Marketers may promote such clues during their promotion advertisement. For example, a TV advertisement may need to emphasize leading role with financial success, is always choosing the specific luxury brand as a symbol of the higher social status. Regarding the act marketing, the results were shown there was no statistically supported the effects of act on trust or self-esteem. The speculative reason may be that the luxury marketing is not similar to the sports or luxury car markets which punctuate the motion, dynamic, speed concept. Act marketing may influence on other psychological elements but not on trust and self-esteem.

The experience of product usage also could enhance consumer trust toward the providers, leading a high level of behavioral intention. Indeed, it could strengthen the consumer self-esteem. This implies managers should promote more experiential marketing activities to let its consumer to experience the product. The experience could let consumer specific touch, feel, and truly understand the higher quality of product, reinforcing the consumer trust toward the providers. Most important, the experiential marketing would increase the effects of information search cost. Based on the luxury scenario in this study, the price of luxury product is normally higher than other product categories. It often leads consumers to look for more information comparing with every detail of product. Constructing the experiential marketing activities can lead consumer generate the higher trust and self-esteem, thus, increase a conscious of time saving (less information search cost).

Regarding the theoretical implications, this paper examined the relationships between the consumer trust and self-esteem with the elements of experiential marketing module. This paper provides an extension of theory of SEMs proposed by 
Schmitt (1999). In addition, the mediation role of information search cost on trust-behavioral intention and self-esteem-behavioral intention was statistically examined. Future research should examine the generalization of the structure of research model and relationships among the constructs.

In addition, this study offers important luxury market implications which accommodate customers' experiential needs that are not only belonging to consumer-centric, but corresponding to context specific. It also reflects the growing recognition of the experiential marketing stimuli, as they were found in advertisement and selling effectiveness. The consequences of experiential marketing on behavioral intention have not been absolutely explored according to extant literature. Future research can examine the differences among the distinct production categories in luxury markets.

\section{References}

[1] Z. U. Ahmed, J. P. Johnson, X. Yang, C. K. Fatt, H. S. Teng, and L. C. Boon, "Does country of origin matter for low-involvement products?" International Marketing Review, vol. 21, no. 1, pp. 102-120, 2004.

[2] C. Amatulli, and G. Guido, "Determinants of purchasing intention for fashion luxury goods in the Italian market: A laddering approach". Journal of Fashion Marketing and Management: An International Journal, vol. 15, no. 1, pp. 123-136, 2011.

[3] J. Arndt, S. Solomon, T. Kasser, and K. M. Sheldon, "The urge to splurge: a terror management account of materialism and consumer behavior". Journal of Consumer Psychology, vol. 14, no. 3, pp. 198-212, 2004.

[4] L. D. Bacon, Using LISREL and PLS to measure customer satisfaction. In Seventh Annual Sawtooth Software Conference, La Jolla CA. 305-306, 1999.

[5] R. P. Bagozzi, and Y. Yi, "On the evaluation of structural equation models". Journal of the Academy of Marketing Science, vol. 16, no. 1, pp. 74-94, 1988.

[6] Bain \& Company, Luxury goods worldwide market study fall-winter 2014 - The rise of the borderless consumer, 2014, available http://www.bain.com/publications/articles/luxury-goods-world wide-market-study-december-2014.aspx, assessed on $18 / 02 / 2015$

[7] R. M. Baron, and D. A. Kenny, "The moderator-mediator variable distinction in social psychological research: Conceptual, strategic, and statistical considerations". Journal of Personality and Social Psychology, vol. 51, no. 6, pp. 1173-1182, 1986

[8] R. F. Baumeister, J. D. Campbell, J. I. Krueger, and K. D. Vohs, "Does high self-esteem cause better performance, interpersonal success, happiness, or healthier lifestyles?" Psychological Science in the Public Interest, vol. 4, no. 1, pp. 1-44, 2003.

[9] Q. Bian, and S. Forsythe, "Purchase intention for luxury brands: A cross cultural comparison". Journal of Business Research, vol. 65, no. 10, pp. 1443-1451, 2012.
[10] J. D. Brown, "Self-esteem and self-evaluation: Feeling is believing". In: Sils, J. (Ed.) Psychological perspectives on the selfLawrence Erlbaum Associates, Hillsdale, pp. 27-58, 1993.

[11] A. Brun, F. Caniato, M. Caridi, C. Castelli, G. Miragliotta, S. Ronchi, A. Sianesi, and G. Spina, "Logistics and supply chain management in luxury fashion retail: Empirical investigation of Italian firms". International Journal of Production Economics, vol. 114, no. 2, pp. 554-570, 2008.

[12] P. N. Danziger, Let them eat the cake: marketing luxury to the masses as well as the classes. Chicago: Dearborn Trade Publishing, 2005.

[13] A. Di Paula, and J. D. Campbell, "Self-esteem and persistence in the face of failure". Journal of Personality and Social Psychology, vol. 83, no. 3, pp. 711-724, 2002.

[14] B. Dubois, and G. Laurent, "Attitudes toward the concept of luxury: An exploratory analysis". Asia-Pacific Advances in Consumer Research, vol. 1, no. 2, pp. 273-278, 1994.

[15] T. Erdem, and J. Swait, "Brand equity as a signaling phenomenon". Journal of Consumer Psychology, vol. 7, no. 2, pp. 131-157, 1998.

[16] T. Erdem, J. Swait, and A. Valenzuela, "Brands as signals: A cross-country validation study". Journal of Marketing, vol. 70, no. 1, pp. 34-49, 2006.

[17] L. R. Fabrigar, D. T. Wegener, R. C. MacCallum, and E. J. Strahan, "Evaluating the use of exploratory factor analysis in psychological research". Psychological Methods, vol. 4, no. 3, pp. 272-299, 1999.

[18] R. Ferraro, B. Shiv, and J. R. Bettman, "Let us eat and drink, for tomorrow we shall die: effects of mortality salience and self-esteem on self-regulation in consumer choice". Journal of Consumer Research, vol. 32, no.1, pp. 65-75, 2005.

[19] C. Fornell, and D. F. Larcker, "Structural equation models with unobservable variables and measurement error: Algebra and statistics". Journal of Marketing Research, vol. 18, no. 3, pp. 382-388, 1981.

[20] L. Gao, M. J. Norton, Z. M. Zhang, and C. K. M. To, "Potential niche markets for luxury fashion goods in China". Journal of Fashion Marketing and Management: An International Journal, vol. 13, no. 4, pp. 514-526, 2009.

[21] E. Garbarino, and M. S. Johnson, "The different roles of satisfaction, trust, and commitment in customer relationships". Journal of Marketing, vol. 63, no. 2, pp. 70-87, 1999.

[22] J. B. Gassenheimer, F. S. Houston, and J. C. Davis, "The role of economic value, social value, and perceptions of fairness in interorganizational relationship retention decisions". Journal of the Academy of Marketing Science, vol. 26, no. 4, pp. 322-337, 1998.

[23] J. Goody, "From misery to luxury". Social Science Information, vol. 45, no. 3, pp. 341-348, pp. 2006.

[24] J. F. Hair, R. E. Anderson, R. L. Tatham, and W. C. Black, Multivariate Data Analysis (5th ed.), Englewood Cliffs, NJ: Prentice-Hall, 1998.

[25] J. F. Hair, M. Sarstedt, C. M. Ringle, and J. A. Mena, "An assessment of the use of partial least squares structural equation modeling in marketing research". Journal of the Academy of Marketing Science, vol. 40, no. 3, pp. 414-433, 2012. 
[26] M. K. Hogg, A. J. Cox, and K. Keeling, "The impact of self-monitoring on image congruence and product/brand evaluation". European Journal of Marketing, vol. 34, no. 5/6, pp. 641-666, 2000.

[27] D. B. Holt, "How consumers consume: A typology of consumption practices". Journal of Consumer Research, vol. 22, pp. 1-16, 1995.

[28] J. Hulland, "Use of partial least squares (PLS) in strategic management research: A review of four recent studies". Strategic Management Journal, vol. 20, no. 2, pp. 195-204, 1999.

[29] H. Hwang, N. K. Malhotra, Y. Kim, M. A. Tomiuk, and S. Hong, "A comparative study on parameter recovery of three approaches to structural equation modeling". Journal of Marketing Research, vol. 47, no. 4, pp. 699-712, 2010.

[30] T. A. Judge, and J. E. Bono, "Relationship of core self-evaluations traits-self-esteem, generalized self-efficacy, locus of control, and emotional stability - with job satisfaction and job performance: A meta-analysis". Journal of Applied Psychology, vol. 86, no. 1, pp. 80-92, 2001.

[31] Ş. Kalaycı, Faktör Analizi, Ş. Kalaycı (Ed.) SPSS Uygulamalı Cok Değișkenli İstatistik Teknikleri (ss. 321-331). Ankara: Asil Yayın Dağıtım Ltd. Şti, 2005.

[32] T. Kasser, The high price of materialism. London: MIT Press, 2002.

[33] K. L. Keller, Strategic Brand Management, Prentice Hall, New York, NY, 2003.

[34] KPMG, Luxury brands in China, , 2006, available at http://www.kpmg.com.cn/en/virtual_library/Consumer_marke ts/CM_Luxury_brand.pdf., accessed on 25/01/2015.

[35] L. Leuthesser, "Defining, measuring, and managing brand equity". (Report No 88-104) Cambridge, MA. Marketing Science Institute, 1988.

[36] G. A. Marcoulides, and C. Saunders, "PLS: A silver bullet?" Management Information Systems Quarterly, vol. 30, no. 2, pp. iii-ix, 2006.

[37] R. C. Mayer, J. H. Davis, and F. D. Schoorman, "An integrative model of organizational trust". Academy of Management Review, vol. 20, no. 3, pp. 709-734, 1995.

[38] Mckinsey \& Co, Luxury Goods and Brands, MGI, Geneva, 1998.

[39] D. G. Mick, and M. DeMoss, "Self-gifts: Phenomenological insights from four contexts". Journal of Consumer Research, vol. 17, no. 3, pp. 322-332, 1990.

[40] C. Moorman, R. Deshpande, and G. Zaltman, "Factors affecting trust in market research relationships". Journal of Marketing, vol. 51, no. 7, pp. 81-101, 1993.

[41] R. M. Morgan, and S. D. Hunt, "The commitment-trust theory of relationship marketing". Journal of Marketing, vol. 58, pp. 20-38, 1994.

[42] A. O'cass, and H. McEwen, "Exploring consumer status and conspicuous consumption". Journal of Consumer Behaviour, vol. 4, no. 1, pp. 25-39, 2004.

[43] R., Pyszczynski, J. Greenberg, S. Solomon, J. Arndt, and J. Schimel, "Why do people need self-esteem? A theoretical and empirical review". Psychological Bulletin, vol. 130, no. 3, pp. 435-468, 2004.

[44] F. F. Reichheld, and P. Schefter, "E-loyalty". Harvard Business Review, vol. 78, no. 4, pp. 105-113, 2000.

[45] J. M. Renaud, and A. R. McConnell, "Wanting to be better but thinking you can't: implicit theories of personality moderate the impact of self-discrepancies on self-esteem". Self and Identity, vol. 6, no. 1, pp. 41-50, 2007.

[46] C. M. Ringle, S. Wende, and A. Will, SmartPLS 2.0.M3. Hamburg: SmartPLS, available at http://www.smartpls.de., accessed on 28/01/2015.

[47] E. Roux, and J. M. Floch, "Gerer l'ingerable: La contradiction interne de toute maison de luxe". Decisions Marketing, vol. 9, pp. 15-23, 1996.

[48] B. Schmitt, "Experiential marketing". Journal of Marketing Management, vol. 15, no. 1-3, pp. 53-67, 1999.

[49] K. M. Sheldon, A. J. Elliot, Y. Kim, and T. Kasser, "What is satisfying events? Testing 10 candidate psychological needs". Journal of Personality and Social Psychology, vol. 80, no. 2, pp. 325-339, 2001.

[50] S. Shugan, "The cost of thinking". Journal of Consumer Research, vol. 7, no. 2, pp. 99-111, 1980.

[51] M. Singh, S. K. Balasubramanian, and G. Chakraborty, "A comparative analysis of three communication formats: advertising, infomercial, and direct experience". Journal of Advertising, vol. 29, no. 4, pp. 135-152, 2000.

[52] D. Sirdeshmukh, J. Singh, and B. Sabol, "Consumer trust, value, and loyalty in relational exchanges". Journal of Marketing, vol. 66, no. 1, pp. 15-37, 2002.

[53] G. W. Snedecor, and W. G. Cochran, Statistical Methods. Eighth Edition, Iowa State University Press, 1989.

[54] M. Tan, and T. Teo, "Factors influencing the adoption of Internet banking". Journal of the Association for Information Systems, vol. 1, no. 5, pp. 1-44, 2000.

[55] Y. Truong, and R. McColl, "Intrinsic motivations, self-esteem, and luxury goods consumption". Journal of Retailing and Consumer Services, vol. 18, no. 6, pp. 555-561, 2011.

[56] S. H. Tsaur, Y. Chiu, and C. H. Wang, "The visitors behavioral consequences of experiential marketing: An empirical study on Taipei Zoo". Journal of Travel \& Tourism Marketing, vol. 21, no. 1, pp. 47-64, 2006.

[57] C. Tynan, S. McKechnie, and C. Chhuon, (2010). "Co-creating value for luxury brands". Journal of Business Research, vol. 63, no. 11, pp. 1156-1163.

[58] G. L. Urban, F. Sultan, and W. J. Qualls, "Placing trust at the center of your Internet strategy". Sloan Management Review, vol. 42, no. 1, 2000, Online available at http://sloanreview.mit.edu/article/placing-trust-at-the-center-of -your-internet-strategy/, accessed on 01/03/2015.

[59] F. Vigneron, and L. W. Johnson, "Measuring perceptions of brand luxury." The Journal of Brand Management, vol. 11, no. 6, pp. 484-506, 2004.

[60] Y. Wang, S. Sun, and Y. Song, "Motivation for luxury consumption: Evidence from a metropolitan city in China". Research in Consumer Behavior, vol. 12, pp. 161-181, 2010. 
[61] K. P. Wiedmann, N. Hennigs, and A. Siebels, "Value-based segmentation of luxury consumption behavior". Psychology \& Marketing, vol. 26, no. 7, pp. 625-651, 2009.

[62] K. K. Wong, "Handling small survey sample size and skewed dataset with partial least square path modeling". Vue: The Magazine of the Marketing Research and Intelligence Association, pp. 20-23, November, 2010.
[63] P. L. Wright, On the direct monitoring of rational response to advertising. in Hughe, G.D. (Ed.). Buyer/Consumer Information Processing, University of North Carolina Press, Chapel Hill, NC, 1974.

[64] S. J. Yoon, "Antecedents and consequences of in-store experiences based on an experiential typology". European Journal of Marketing, vo., 47, no. 5/6, pp. 693-714, 2013. 